(C) 2011 by Chelonian Research Foundation • Published 31 December 2011

\title{
Cuora amboinensis (Riche in Daudin 1801) - Southeast Asian Box Turtle
}

\author{
SABINE SChOPPE ${ }^{1}$ AND INDRANEIL DaS ${ }^{2}$ \\ ${ }^{1}$ Katala Foundation Inc., P.O. Box 390, Puerto Princesa City, \\ PH-5300 Palawan, Philippines [sabine_schoppe@web.de]; \\ ${ }^{2}$ Institute of Biodiversity and Environmental Conservation, \\ Universiti Malaysia Sarawak, 94300 Kota Samarahan, Sarawak, Malaysia [idas@ibec.unimas.my]
}

\begin{abstract}
Summary. - The Southeast Asian Box Turtle, Cuora amboinensis (Family Geoemydidae), is a small (straight carapace length to $25 \mathrm{~cm}$ ), semi-aquatic turtle, largely restricted to standing water bodies of Southeast Asia, from eastern India to Indonesia and the Philippines. It has four currently recognized subspecies: $C$. a. amboinensis, $C$. a. couro, $C$. a. kamaroma, and $C$. a. lineata. The species is still relatively common in most of its range, perhaps due to its ability to adapt to a variety of habitats, including rice fields and the vicinity of human settlements. Diet includes both plant and animal matter. The species lays 1-4 large (24-34 x 44-57 mm) eggs with masses of 14-31.5 g. The considerable variation in egg size, incubation period, and reproductive season, as evident from data derived from captive breeding, is thought to be reflective of geographic variation in this widespread turtle species. The species is currently listed as Vulnerable by the IUCN Red List due to its heavy exploitation for the international food, pet, and medicinal trade, and is also included in CITES Appendix II. There is an apparently large illegal trade in the species, and many regional populations appear to be decreasing rapidly, requiring closer monitoring.

Distribution. - Bangladesh, Brunei Darussalam, Cambodia, India, Indonesia, Laos, Malaysia, Myanmar, Philippines, Singapore, Thailand, Timor-Leste, Vietnam. Widely distributed from northeast India and Bangladesh, through most of mainland Southeast Asia to the islands of East Malaysia, Indonesia, Timor-Leste, and the Philippines.

Synonymy. - Testudo melanocephala Van-Ernest in Daudin 1801 (nomen oblitum), Emys melanocephala, Clemmys (Clemmys) melanocephala, Testudo amboinensis Riche in Daudin 1801, Emys amboinensis, Terrapene amboinensis, Cistuda amboinensis, Cuora amboinensis, Cistudo amboinensis, Cyclemys amboinensis, Emys (Cistuda) amboinensis leveriana Gray 1830.

SuBSPECIES. - Four currently recognized: 1) Cuora amboinensis amboinensis (East Indian Box Turtle, Wallacean Box Turtle) (distribution: Sulawesi and northeastern Indonesia and Philippines); 2) Cuora amboinensis couro (Indonesian Box Turtle) (synonymy: Emys couro Schweigger 1812, Terrapene bicolor Bell 1826) (distribution: Sumatra and southern Indonesia); 3) Cuora amboinensis kamaroma Rummler and Fritz 1991 (Malayan Box Turtle) (distribution: Kalimantan, Malaysia, and continental Southeast Asia); and 4) Cuora amboinensis lineata McCord and Philippen 1998 (Burmese Box Turtle) (distribution: northern Myanmar).

STatus. - IUCN 2011 Red List: Vulnerable (VU A1d+2d) (assessed 2000); CITES: Appendix II, as Cuora spp.
\end{abstract}

Taxonomy. - Testudo amboinensis Riche in Daudin 1801 was described from the island of "Amboine" (=Ambon, Maluku [formerly,Amboyne,Moluccas],Indonesia). Daudin (1801), however, mentioned that the type was lost at sea before he saw it (see also Bour in Rummler and Fritz 1991) and copied the description of the species from a manuscript by the French naturalist Claude-Antoine-Gaspard Riche (1762-1797). Bourret (1941) mentioned that the type is in the Musée National d'Histoire Naturelle, Paris, France, but it cannot be located there at present. Synonymies include Testudo melanocephala Van-Ernest in Daudin 1801, Emys (Cistuda) amboinensis leveriana Gray 1830, and Terrapene bicolor Bell 1826. Four subspecies have been generally recognized (see Rummler and Fritz 1991; McCord and Philippen 1998): C.a.amboinensis (Riche in Daudin 1801),
C. a. couro (Schweigger 1812), C. a. kamaroma (Rummler and Fritz 1991), and C. a. lineata (McCord and Philippen 1998). However, many of the supposed diagnostic features of these subspecies overlap with each other, and genetic analyses of the various populations are required.

Molecular data reveal that C. amboinensis is a member of the Cuora sensu lato group, including taxa formerly allocated to Pyxidea and Cistoclemmys (see Honda et al. 2002; Spinks and Shaffer 2007), that currently includes 12 nominal species. Key to the contents of the genus (excluding C. mouhotii and including several nomina that are at present considered hybrids) can be found in McCord and Iverson (1991). Hybrids between C. amboinensis kamaroma and Mauremys reevesii have been reported from turtle farms in China (Ye et al .2009). Vetter and van Dijk (2006) picture six 


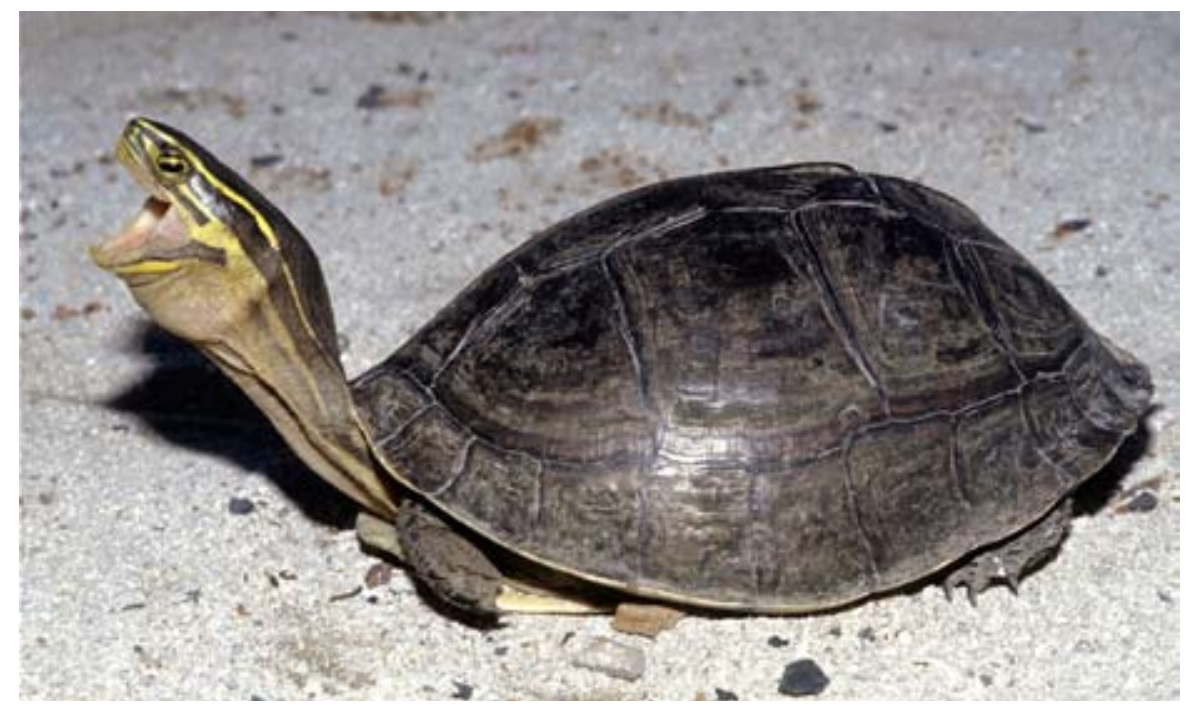

Figure 1. Cuora amboinensis kamaroma from Nicobar Islands, India. Photo by Indraneil Das.

hybrids involving C.amboinensis, namely Chinemys reevesii, C. nigricans, Cathaiemys mutica, Malayemys subtrijuga, Pyxiclemys trifasciata, and Siebenrockiella crassicollis.

Description. - Shell shape ranges from flat-topped to highly domed, depending on the subspecies. The posterior edge of the carapace is unserrated. The carapace itself is with or without sloping sides, and tricarinate in young, with keels disappearing during growth. Adistinct hinge is present between the hyo- and hypoplastron; the plastron is united to the carapace by ligaments in adults. As in its congeners, closure of the anterior plastral lobe is controlled by the testoscapularis muscle (Bramble 1974).

The carapace is dark olive, brown to black, whereas the plastron is yellow, cream, or pale brown, with or without dark blotches on the marginals and on the outer edges of the plastral scutes. These plastral markings are reportedly largest in the nominate subspecies. The head is dark brown or green above, yellow below, with three yellow or orangish-yellow bands running across the sides of the head. Limbs are olive or yellowish-gray. Digits are entirely webbed.

The karyotype is $2 \mathrm{n}=52$ (Stock 1972; Killebrew 1977; Carr and Bickham 1986; Guo 1997) or 2n $=50$ (Kiester and Childress in Gorman 1973).

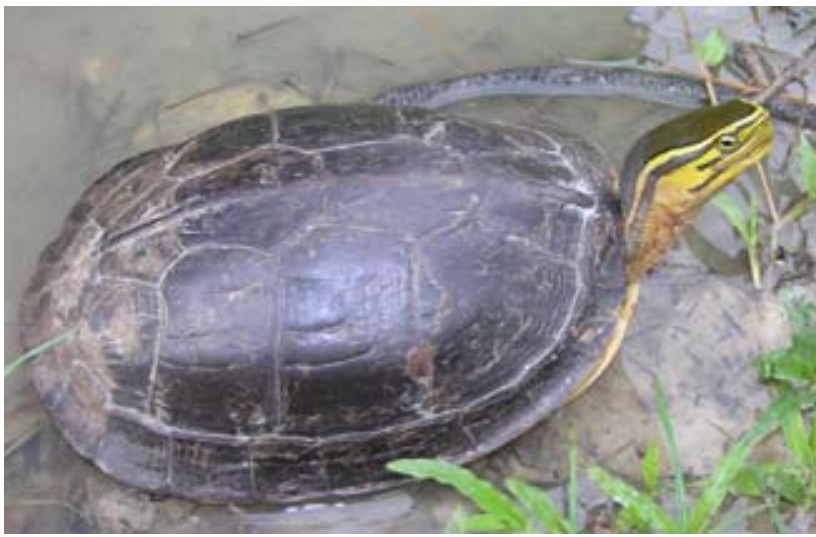

Figure 2. Cuora amboinensis amboinensis, Sulawesi, Indonesia. Photo by Sabine Schoppe.
Cuora amboinensis is a small turtle; the various subspecies vary slightly in size with C.a. kamaroma being the largest. Lim and Das (1999) recorded a carapace length (CL) of $250 \mathrm{~mm}$ for the Malayan subspecies, C. a. kamaroma. Next in size is the Burmese Box Turtle, C. a. lineata, with a maximum CL of $230 \mathrm{~mm}$ (McCord and Philippen 1998), followed by the Indonesian Box Turtle, C. a. couro, with a recorded maximum CL of $217.5 \mathrm{~mm}$ (Rummler and Fritz 1991), and smallest is the East Indian Box Turtle, C. a. amboinensis, with a maximum record of $200 \mathrm{~mm} \mathrm{CL}$ (Schoppe 2009). The maximum weight of $1650 \mathrm{~g}$ at a CL of $199 \mathrm{~mm}$ for a female and $1950 \mathrm{~g}$ at a CL of $172 \mathrm{~mm}$ for a male Ma-
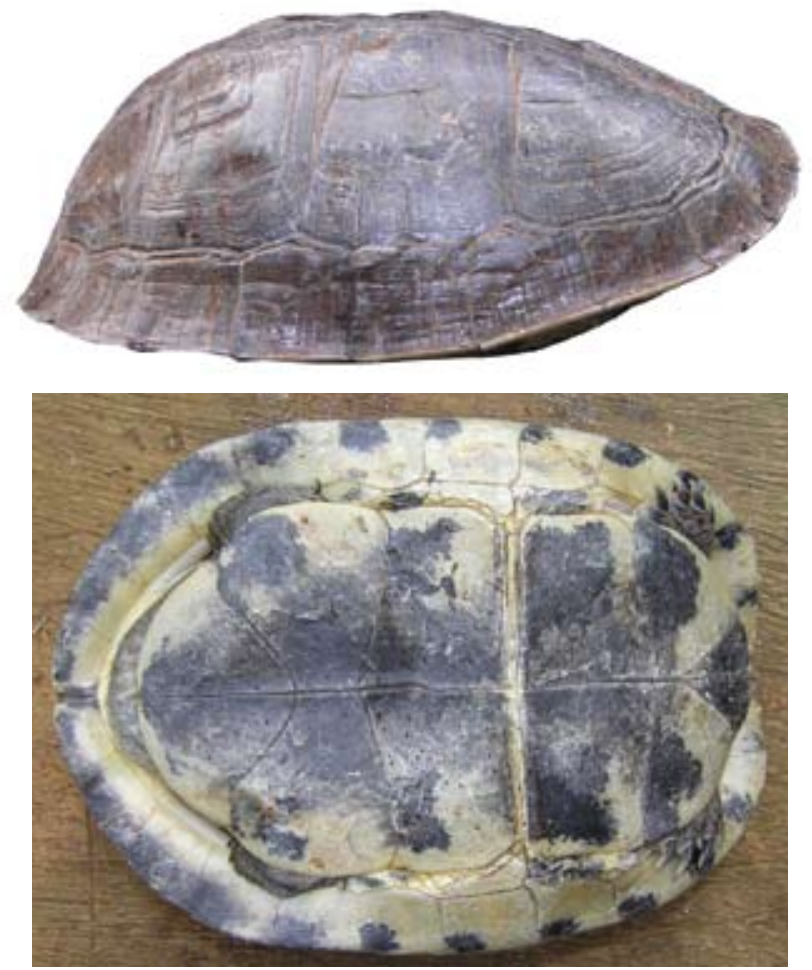

Figure 3. Cuora amboinensis couro, Indonesia. Photos by Sabine Schoppe. 


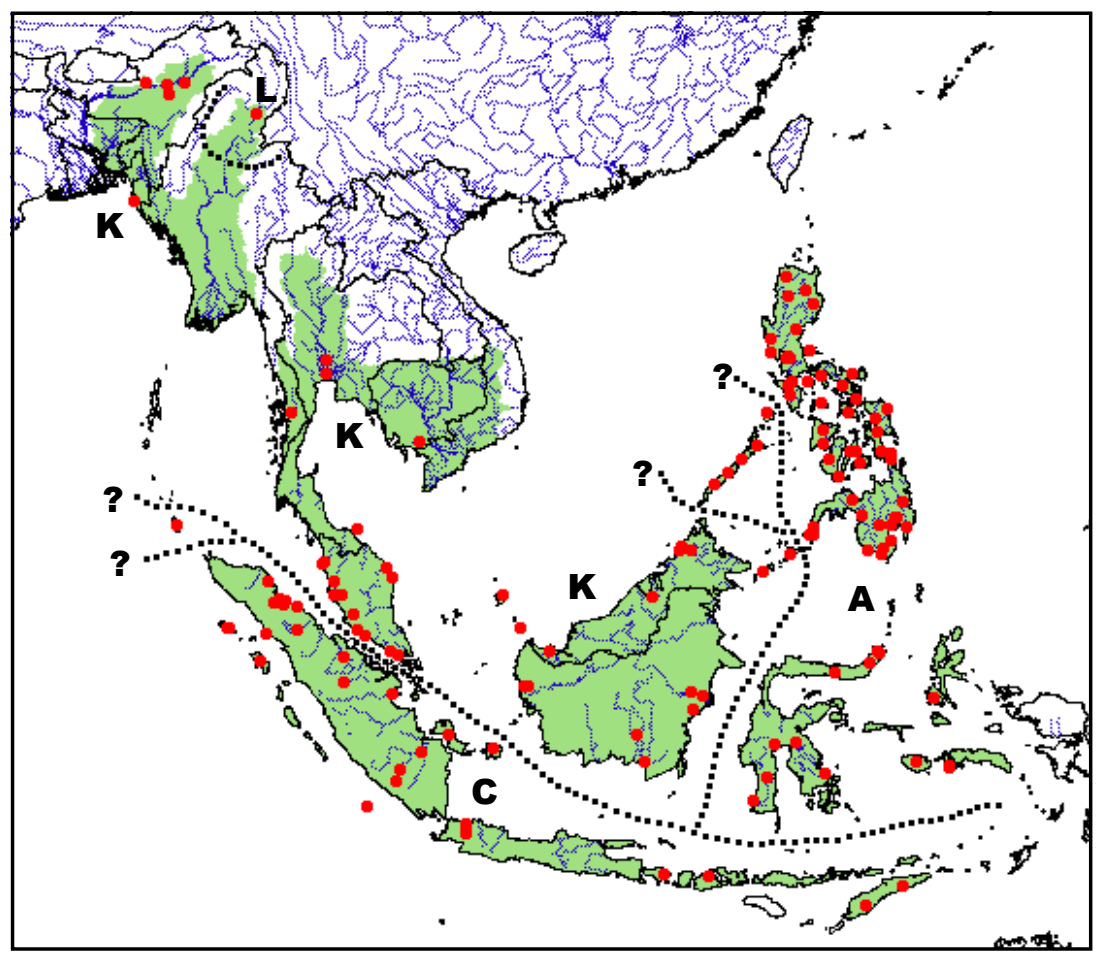

Figure 4. Distribution of Cuora amboinensis in Southeast Asia, with dotted lines indicating approximate subspecies boundaries: $\mathrm{A}=$ amboinensis, $\mathrm{C}=$ couro, $\mathrm{K}=$ kamaroma, $\mathrm{L}=$ lineata; lines marked with question marks indicate populations on Palawan and the Nicobars, which are of questionable subspecies status and may represent intergrades. Red dots $=$ museum and literature occurrence records of native populations based on Iverson (1992), plus more recent and authors' data; green shading $=$ projected distribution based on GIS-defined hydrologic unit compartments (HUCs) constructed around verified localities and then adding HUCs that connect known point localities in the same watershed or physiographic region, and similar habitats and elevations as verified HUCs (Buhlmann et al. 2009), and adjusted based on authors' data.

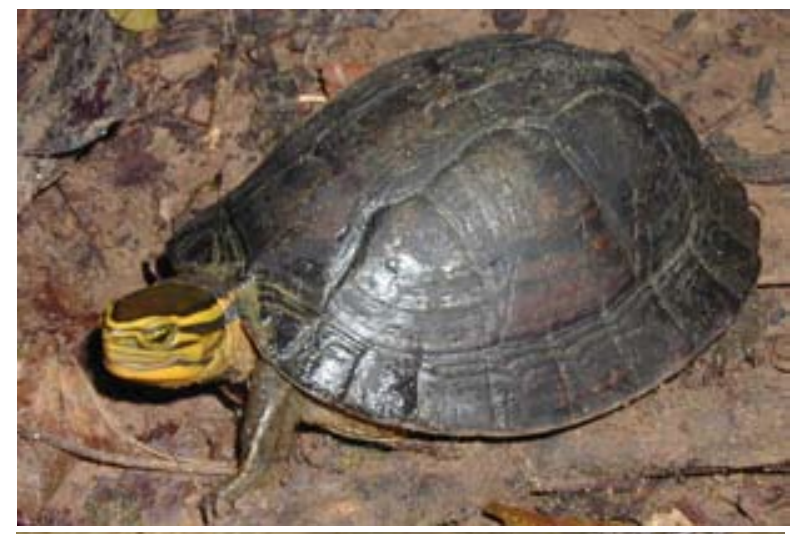

layan Box Turtle, respectively, constitute the known weight record for the species (Schoppe 2009).

Life expectancy is 25-30 years; a maximum age of 38.2 years was recorded for an animal in captivity (Bowler 1977). Generation time is ca. 18 years (Schoppe 2008, 2009). The sex ratio is 1:1 or slightly in favor of females (Schoppe 2008, 2009). Sexual dimorphism is evident at around 15 months (Schoppe 2008, 2009). Males are generally slightly smaller and lighter than females (Rummler and Fritz 1991; Schoppe 2008, 2009). Males possess a relatively longer tail and a slightly concave plastron. Males mature at a CL of $130 \mathrm{~mm}$, females at $152 \mathrm{~mm}$ (Paull et al. 1982).

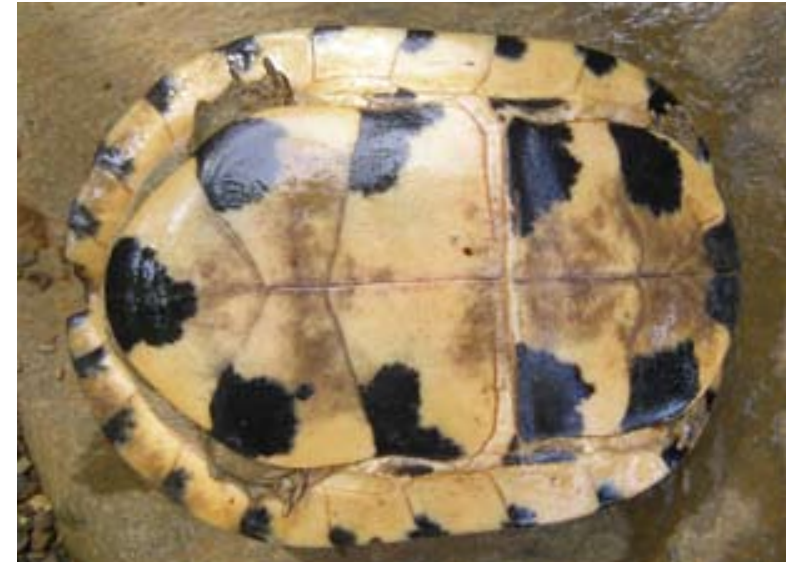

Figure 5. Cuora amboinensis kamaroma (?), Palawan, Philippines. Photos by Sabine Schoppe.

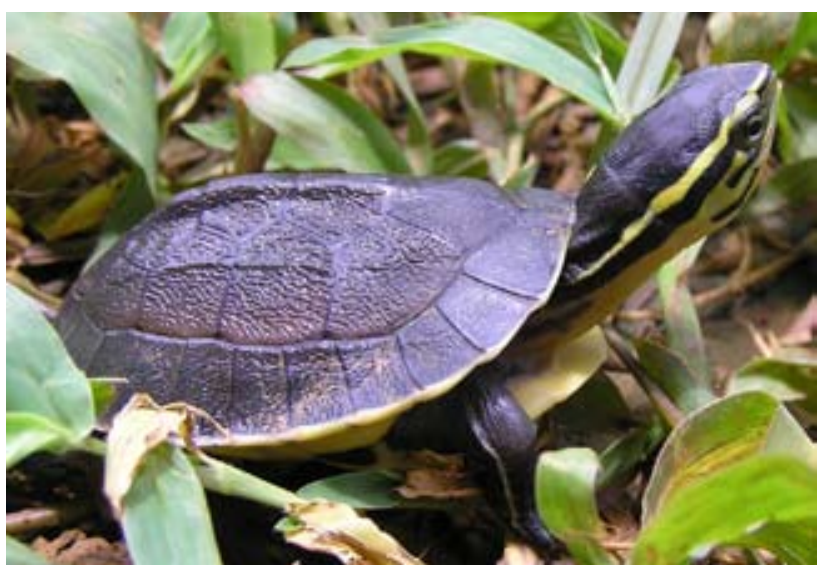

Figure 6. Hatchling Cuora amboinensis kamaroma (?), Palawan, Philippines. Photo by Sabine Schoppe. 


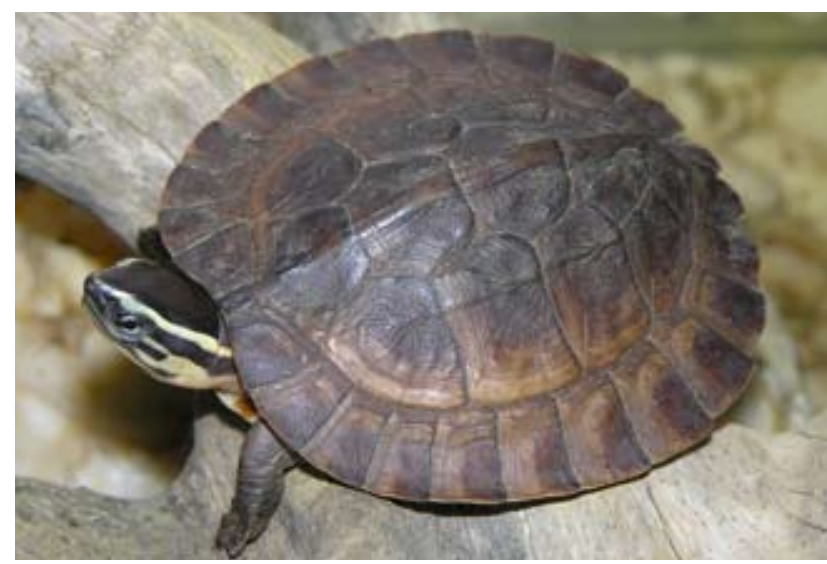

Figure 7. Juvenile Cuora amboinensis amboinensis, Luzon, Philippines. Photo by Sabine Schoppe.

Four subspecies are currently recognized: the East Indian Box Turtle, C. a. amboinensis (Riche in Daudin 1801), also referred to as the Wallacean Box Turtle, the Malayan Box Turtle, C. a. kamaroma Rummler and Fritz 1991, the Indonesian Box Turtle, C. a. couro (Schweigger 1812), and the Burmese Box Turtle, C.a. lineata McCord and Philippen 1998. Rummler and Fritz (1991) provided morphometric values such as body ratios for carapace length to body height and carapace width to body height that distinguish the first three subspecies. Accordingly, $C$. a. amboinensis is characterized by a flat, broad carapace with distinct margin; C. a. kamaroma is highly domed and has a narrower carapace without a well-developed margin; whereas the shell of C.a.couro shows intermediate characters (Rummler and Fritz 1991). They also noted subtle color differences in cephalic pattern (particularly head stripes), carapace color, extent of plastron blotches, and expression of vertebral and lateral costal keels. Cuora a. lineata on the other hand can be distinguished from the former three subspecies by the total lack of carapacial keels, diminished inguinal scutes, a more flared posterior plastral lobe allowing a more completely closed posterior shell opening, and a yellowish white middorsal stripe (McCord and Philippen 1998).

The two subspecies that are found in the Philippines, $C$. a.amboinensis and C.a.kamaroma (Gaulke 1995a,b; Gaulke and Fritz 1998), might in fact constitute morphologically

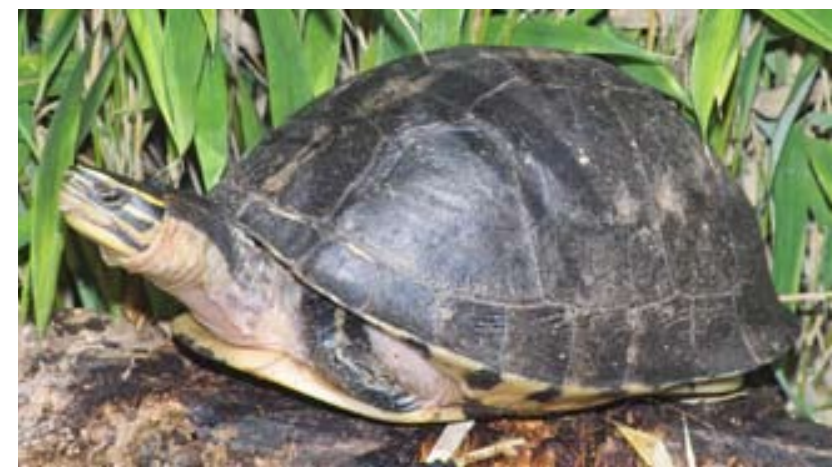

Figure 8. Cuora amboinensis lineata from Myanmar. Photo by Hans-Dieter Philippen. different forms from their conspecifics in Sulawesi and Borneo (Schoppe, pers. obs.).

For the subspecies that occurs on Palawan in the Philippines (currently assigned to C. a. kamaroma), eggs $(\mathrm{n}=87)$ normally range from $44-57 \mathrm{~mm}$ in length (mean = $50.6 \pm 3.0 \mathrm{~mm}$ ), from $24-31 \mathrm{~mm}$ in width (mean $=27.6 \pm$ $1.7 \mathrm{~mm}$ ), and from $14-24 \mathrm{~g}$ in weight (mean $=21.7 \pm 4.7 \mathrm{~g}$ ) (Schoppe 2010). The eggs of the other subspecies are within this range (Praedicow 1985; Grychta 1989). The smallest egg ever encountered measured $35 \times 23.8 \mathrm{~mm}$ and weighed $11 \mathrm{~g}$ (Schoppe 2010).

Ewert (1979) provided data on hatchling CL: $47.3 \mathrm{~mm}$ for the "domed biotype" (presumably the subspecies kamaroma and/or couro) and $48.8 \mathrm{~mm}$ for the "depressed biotype" (the subspecies amboinensis). Mudde (1987) reported hatchling CL of 38-48 mm (mean $43.8 \mathrm{~mm}$ ) and mass of 11.5-18.0 g (mean $15.8 \mathrm{~g})$. Hatchlings of the Palawan subspecies ( $\mathrm{n}=$ 54) measured between 39 and $49 \mathrm{~mm}$ in CL (mean $=43.5 \pm$ $2.5 \mathrm{~mm}$ ), between 27 and $52 \mathrm{~mm}$ in CW (mean $=34.5 \pm 4.5$ $\mathrm{mm}$ ), and weighed between 11 and $22 \mathrm{~g}$ (mean $=15 \pm 2.9 \mathrm{~g}$ ) (Schoppe 2010). The smallest ever reported C. amboinensis hatchlings measured $33 \mathrm{~mm} \mathrm{CL}, 28.9 \mathrm{~mm} \mathrm{CW}$, and weighed $7 \mathrm{~g}$ (Schoppe 2010).

Distribution. - Cuora amboinensis is widespread in Southeast Asia, both on the Asian mainland and on the oceanic and continental islands. Its distribution extends from northeast India through Bangladesh, Myanmar and Thailand, to Laos, Vietnam, Cambodia, the Malay Peninsula, and the Greater Sundas, to eastern Indonesia and the Philippines (Rummler and Fritz 1991; Fritz and Havas 2007).

The East Indian or Wallacean Box Turtle, C.a.amboinensis, occurs on the Moluccas, Sulawesi, and the Philippines (except the Sulu Archipelago) (Fritz and Havas 2007; Diesmos et al. 2008). The Malayan Box Turtle, Cuora $a$. kamaroma, occurs from northeastern India and Bangladesh through southeastern Asia to the Malay Peninsula, Nicobar Islands, Borneo, Sulu Archipelago, and perhaps Palawan Island group, Philippines (Fritz and Havas 2007; Diesmos et al. 2008). The hypothesis that Palawan populations may

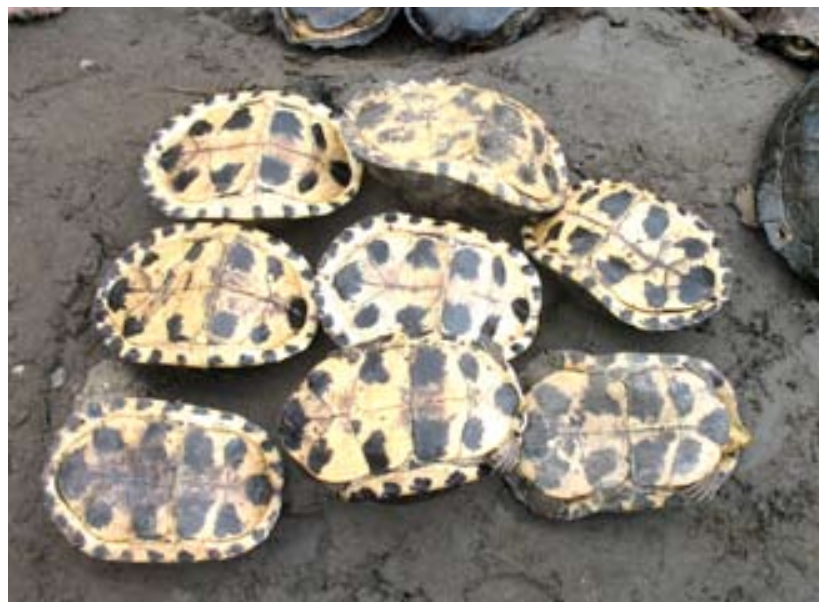

Figure 9. Cuora amboinensis lineata for sale in a trader's shop in Myitkyina, Kachin State, northern Myanmar. Photo supplied by Kalyar Platt. 
represent an undescribed taxon warrants further study (Schoppe, unpubl. data). The Indonesian Box Turtle, C. $a$. couro, occurs on Sumatra, Java, Sumbawa and their smaller, satellite islands (Fritz and Havas 2007), including Timor and probably Timor-Leste (Ibarrondo in Kuchling et al. 2007). The Burmese Box Turtle, Cuora a. lineata, is restricted to Myanmar, and confirmed only from Kachin Province in the north (Fritz and Havas 2007).

Habitat and Ecology. - Cuora amboinensis is a habitat generalist, adaptable to anthropogenically altered habitats, including towns and villages (Moll 1997; Schoppe 2008). In general, the ecological and morphological similarity to the Nearctic Terrapene is remarkable (see Ernst et al. 1997), down to details of fire scars (Ives et al. 2008). The species is widely distributed in lowland freshwater habitats from sea level to about $500 \mathrm{~m}$ asl. Individuals may wander substantial distances over the course of a lifetime, but the species does not migrate seasonally or to any geographically significant extent. It is semi-aquatic, inhabiting various natural and man-made wetlands with soft bottoms and slow or no current (Ernst et al.2000). Natural and human-modified habitats and their margins utilized by the species include marshes, creeks, mangrove swamps, ponds, peat swamp forests, Melaleuca swamps, permanent or temporary wetlands, shallow lakes, sometimes rivers, flooded rice fields, oil palm and rubber plantations that are either partly flooded or that have an extensive drainage system, as well as in irrigation ditches, canals, orchards, vegetated drainage systems, ponds and pools near houses (Das 1991; Sharma and Tisen 2000; Schoppe 2008, 2009).

The young are more aquatic than the adults that, at least in captivity, spend the night on land. A study on activity of this species and other syntopic geoemydid turtles in Sarawak, Borneo, suggests greater activity during overcast periods, and activity during major lunar phases (Jensen and Das 2008a). Alcala (1986) wrote that the turtle hides under debris along stream banks during the day, and is primarily nocturnal.

Cuora amboinensis is omnivorous but primarily vegetarian in diet (Rogner 1996). Nutaphand (1979) noted that aquatic plants, mollusks, and crustaceans are taken in water; while on land, the turtle feeds on land plants, fungi, and worms. It is a predator of various invertebrates (Alcala 1986), and therefore might help to stem occurrence of invertebrate-borne diseases (van Dijk 2000). On Sulawesi, the feces of two individuals contained vegetation, fruits, and seeds (Ives et al. 2008), and three individuals examined at Loagan Bunut, Sarawak, contained fruits and seeds (Jensen and Das 2006). Seed dispersal has been confirmed for at least five important trees (e.g., fig trees Ficus spp., Indian mulberry Morinda citrifolia; Peter Widmann, pers. comm.). The Malayan box turtle is able to feed on land as well as in water. During terrestrial feeding, the initial food prehension is by the jaws, while intraoral food transport and pharyngeal packing actions are tongue-based, and during aquatic feeding, prey is captured by a fast forward head strike (Natchev et al. 2009).
Mating takes place between November-April, and 1-2 eggs were produced in late February and mid-April (Praedicow 1985). Schoppe (pers. obs.) observed mating year around in the Philippines. Grychta (1989) found that smaller females are preferred by males. Paull et al. (1982) observed courtship and copulation in captivity. The male extends the head, first to one side of the female's head, then to the other, about a second a side. In turn, the female extends her head with the mouth open and bobs it slightly in a vertical plane. Within five minutes of these activities, the two then stroke each other's chins for about half a minute, and copulation takes place soon thereafter. Inskeep's (1984a, 1984b) males were aggressive when courting, circling the female a few times before trying to copulate, and biting the female on the neck if she tried to resist. Mudde (1987) also found males to be aggressive to one another. The most detailed observations on courtship and mating in the species have been those of Praedicow (1985). The male approaches the female from the front, with fully extended neck, the mouth opening and closing in succession, and scratches the sides of the female's head rhythmically 15-20 times. When the female tries to bite the male's head, mounting takes place, with the male attempting to bite the female on the head or neck. Courtship and mating at the Melbourne Zoo occurred from August to June, usually in 10-20 day periods, and eggs were laid in September (Chris Banks, pers. comm.). One or two eggs were laid at a time, measuring $48-57 \mathrm{~mm}$ (mean 52) $\mathrm{x}$ 27-31 mm (mean 29), with masses of 14.7-31.5 g (mean 23.1). At $30.5-31^{\circ} \mathrm{C}$, eggs hatched in 47 days, while at $27.5-28.5^{\circ} \mathrm{C}$, the incubation period lasted for 78 days.

The species produces small clutches (Schoppe 2008; 2009).A mean of three clutches with two eggs each resulting in a total of six eggs per female per year are laid in captivity by the Palawan population (Schoppe 2008, 2009). A clutch size of five is also known (Rogner 1996). Eggs are laid from November to August (Schoppe, pers. obs.).

At $23-32^{\circ} \mathrm{C}$ and $60-90 \%$ humidity, the incubation period was 76-77 days (Praedicow 1985). The hatchlings emerged at the end of June, presumably the high water period in their natural range. Between $28-29^{\circ} \mathrm{C}$, the same author obtained hatchlings after 74 to 78 days. Following an oxytocin injection, Grychta's (1989) female laid a single egg in early June and one at the end of November, measuring $55 \times 25 \mathrm{~mm}$ and $50 \times 25 \mathrm{~mm}$, respectively. The latter hatched at the beginning of February, after an incubation period of 68 days, at $27-29^{\circ} \mathrm{C}$ and nearly $100 \%$ humidity. Whitaker and Andrews (1997) noted an incubation period of 67-77 days in the wild and 76-77 days in captivity. At $25-30^{\circ} \mathrm{C}$, Lim and Das (1999) recorded incubation periods of 70-100 days. Schoppe (pers. obs.) observed a range of 60-120 incubation days $(n=22$, mean $88.8 \pm 12.5$ ) in captivity under outdoor conditions $\left(26-30^{\circ} \mathrm{C}\right)$ for the Palawan population, and assumes that a prolonged incubation is related to unsuitable weather conditions. Peak hatching is between May and August during the Palawan rainy season (Schoppe, pers. obs.). Hatching success is about $50 \%$ in captivity under outdoor conditions 
(Schoppe, pers. obs.). Survival rate of eggs and hatchlings in the wild is not known.

Eggs are elongate, brittle, and hard-shelled. Inskeep (1984a, 1984b) found eggs in captivity in the months of April, May, and June. These eggs were all laid during the dry to the beginning of the wet period in the natural range of the species. Bhaskar (1981) found a clutch of two eggs at the Bay of Bengal on Trinkat Island, Great Nicobar, in January, one of which measured 25 x $50 \mathrm{~mm}$. Saxena (1994) presented data from captive reproduction, based on a female from Nicobar Islands. Three single eggs were produced at intervals of 36 and 39 days, eggs measuring 51.7 x 29.6 to $49.6 \times 28.4 \mathrm{~mm}$. One egg that produced a hatchling after 86 days was incubated at $28.5-28.8^{\circ} \mathrm{C}$.

The animals observed by Paull et al. (1982) produced clutches comprising 1-4 (typically 2 or 3 ) eggs, measuring 40-46 x 30-34 mm. Three to five eggs are laid by animals from Thailand (Nutaphand 1979). Mudde (1987) found differences in the dimensions of fertile and infertile eggs, the first measuring 52 × $26 \mathrm{~mm}$, while eggs measuring $45 \times 30$ $\mathrm{mm}$ were infertile. His animals produced 1-2 eggs per clutch on the surface or in nests $5 \mathrm{~cm}$ deep, during the months of June, July, September, and November, apparently within the Southwest Monsoons in Southeast Asia. One egg took 79 days to hatch at $26^{\circ} \mathrm{C}$, two took 94 and 100 days at $28^{\circ} \mathrm{C}$, and two took 66 and 91 days at $30^{\circ} \mathrm{C}$. The considerable variability in clutch size, egg size, and egg-laying season in these data, derived mostly from captives of unknown origin, may be suggestive of geographic variation in reproduction.

Praedicow (1985) observed a mean growth increment of $0.19 \mathrm{~mm}$ per day for two hatchlings during the first six months after hatching in captivity. Studies on captive individuals from Palawan revealed a similar growth rate of 0.24 $\mathrm{mm}$ /day (Schoppe and Dolorosa, unpubl. data). Subadult size $(C L \geq 115 \mathrm{~mm})$ is reached after about 15 months. For subadult animals up to 24 months of age, a mean growth rate of $0.06 \mathrm{~mm} /$ day was calculated, and for adults a mean growth rate of $0.038 \mathrm{~mm} /$ day was calculated, implying that an adult size of $160 \mathrm{~mm} \mathrm{CL}$ is reached in four years and five months in captivity (Schoppe and Dolorosa, unpubl. data). Praedicow (1985) observed sexual maturity of females and males at 5-6 and 8-9 years, respectively. Moll observed a captive Malayan Box Turtle male that appeared to be mature in its fifth year (Edward O. Moll, pers. comm.). Schoppe (pers. obs.) presumes that it takes approx. 4.5-5 years to attain maturity in captivity and at least one more year to reach that stage in the wild.

Eggs and a significant proportion of hatchlings are an important source of food for monitor lizards, crocodiles, herons, and other wetland/riverine birds, and small mammalian predators, such as civets (Moll and Moll 2004). Stanner (2010) observed predation by the water monitor lizard, Varanus salvator, in Bangkok, Thailand.

A substantial amount of information on parasites of the species exists in the literature. This includes endohelminthic nematodes, such as Camallanus intermedius (reported from intestine, Myers and Kuntz 1969),Falcaustra duyagi (cecum,
Tubangui and Villaamil 1933; intestine, Berry 1984, Sharma 2001, Murray 2004); F. greineri (intestine, Murray 2004), Serpinema octorugatum (intestine, Sharma 2001, Sharma et al. 2002, Murray 2004), and Spironoura robert (rectum, Chou and Lowe 1984). The following trematodes have also been recorded from the species: Diaschorchis multitesticularis (intestine, Brooks and Palmieri 1978), Hemiclepsis guandongensis (skin, Tan and Liu 2001), Multicotyle purvisi (stomach and duodenum, Rohde 1971), Neopolystoma liewi (eye, du Preez and Lim 2000; conjunctival sac, Verneau et al. 2011), Neopronocephalus orientalis (upper small intestine, Brooks and Palmieri 1979), Parapleurogonius brevicaecum (intestine, Brooks and Palmieri 1979), Renigonius cuorensis (small intestine, Brooks and Palmieri 1979), Spinometra gigantica (duodenum and ileum, Dwivedi 1965), Spirhapalum elongatum (mesentery, Rohde et al. 1968, Brooks and Palmieri 1979), Stunkardia dilymphosa (large intestine, Rohde 1962a; duodenum and ileum, Dwivedi 1967), S. minuta (intestines, Palmieri and Sullivan 1977, Sey and Palmieri 1978, Murray 2004), Parorientodiscus magnus (large intestine, Rohde 1962b, Sharma 2001), and Telorchis cyclemidis (intestine, Tubangui 1933, Wharton 1970). The following monogenean parasites have been recorded from C. amboinensis: Polystomoides malayi (urinary bladder, Rohde 1963, 1972, Sharma 2001), P. asiaticus (oral cavity, Sharma 2001, Verneau et al. 2011), and Polystomoidella mayesi (urinary bladder, Richardson and Brooks 1987, Murray 2004). Additional parasites known to be associated with the species include the protistic enteromonad, Enteromonas (Kolisko et al. 2008), the blood fluke, Spirhapalum siamensis (heart, Tkach et al. 2009) and the amoebic protozoan, Entamoeba invadens (Barnett 2003).

Population Status. - The species is perhaps an appropriate example of a taxon that has demonstrated a rapid global decline in a short period of time. In 1994, C. amboinensis was unlisted in the IUCN Red List (implying a Least Concern status). Two years later, its status was categorized as Lower Risk: Near Threatened (Baillie and Groombridge 1996). During the next assessment (Hilton-Taylor 2000), the status was Vulnerable (VU) A1d+2d. Its status has not been formally re-assessed since 2000 (Anonymous 2004) and most country information needs updating. However, a preliminary assessment carried out in early 2011 indicated that the species appears to warrant a status category of Vulnerable, and is not yet formally being considered Endangered (P.P. van Dijk and A. Rhodin, unpubl. data).

In the 1970 s, the species was described as numerous in Thailand (Nutaphand 1979), but by the 1990s, population declines were reported (Thirakhupt and van Dijk 1994), and the species is currently considered Vulnerable in the country (IUCN 2009). It is seriously threatened in Vietnam and "few if any viable populations are likely to exist in Vietnam" (Hendrie 2000). Rashid and Khan (2000) report it as an uncommon species in Bangladesh. It has been recorded from southeastern Bangladesh, including Cox's Bazar and Kaptai Lake in Chittagong (Kabir et al. 2009) and northeastern Bangladesh, including Salutikar 
in Sylhet (Frazier and Das 1994). Currently, this species is not included in the Bangladesh Wildlife (Preservation) (Amendment) Act, 1974 (Kabir et al. 2009). In southwest Cambodia, the species was found to be fairly abundant in several localities (David Emmett, pers. comm.), while it is one of the two most threatened turtle species in Laos and described as "valuable and nearly extinct" (Salter 1993). Based on the 2000 IUCN assessment the species is considered Endangered in Bangladesh, Cambodia, Laos, and Vietnam (IUCN 2009). McCord and Philippen (1998) suspected significant over-exploitation of the Myanmar populations due to trade to China. The population is Singapore is small but presumably stable (IUCN 2009).

As for most range countries, the conservation status remains data deficient in the Philippines (Rhodin 2003). Alcala (1986) considered it common all over the country some 20 years ago, but at present, the species remains relatively common only on Polillo Island, Luzon (Alviola et al. 2003) and Palawan (Gavino and Schoppe 2004; Fidenci 2004; Fidenci and Castillo 2009). Populations are, however, decreasing in densely settled areas due to subsistence collection and demand as pets in Palawan (Widmann 1998; Fidenci and Castillo 2009), as well as in the rest of the Philippines (Ministry of Environment, Nature Conservation and Nuclear Safety of the Philippines, in litt. to German Scientific CITES Authority, 10 October 1999; Alviola et al. 2003). Quantitative data are basically absent. Population surveys on the Philippine Forest Turtle Siebenrockiella leytensis in lowland stream habitats caught an average of 3.8 C. amboinensis / ha (4.2-9.8 individuals/ha) in northern Palawan in 2007 (Schoppe unpubl. data). Surveys of undergraduate students calculated $9.2 \mathrm{ind} /$ ha in a swamp forest with adjacent coconut plantation and $3.8 \mathrm{ind} / \mathrm{ha}$ in a swamp-rice field area in southern Leyte in 2010, and $3.1 \mathrm{ind} / \mathrm{ha}$ in a mixed swamp-rice field habitat in southern Palawan in 2011 (Schoppe, pers. comm.).

More recent data are available for Malaysia and Indonesia (Schoppe 2008; 2009). Ten years ago, it was still considered the most common turtle in the wild and in markets in Borneo and in Peninsular Malaysia (Lim and Das 1999), and common and vulnerable in Selangor (Azrina and Lim 1999). It was said to be abundant within those states of Malaysia that still had swamps and manmade wetlands (Sharma and Tisen 2000), and reduced in multiple locations (Sharma 1999; Sharma and Tisen 2000). Some consider it extremely vulnerable to over-exploitation owing to lack of specific legislation regulating exploitation (Jenkins 1995; Gregory and Sharma 1997; Azrina and Lim 1999; Sharma 1999; Shepherd et al. 2004). IUCN (2011) considers the status Vulnerable in Malaysia. According to Schoppe (2008), numbers are reduced and in decline.A study on the abundance of the species in harvest at two traders' premises in Peninsular Malaysia in 2006, indicated low abundance that might be either related to habitat (most are collected from plantations) or to over-exploitation(Schoppe 2008). A survey to estimate population size found only a total of 24 individuals at a density of 0.82 individuals/ha in an oil palm plantation in Selangor. It is probable that this number is too low to sustain reproduction and recruitment (Schoppe 2008).

In Indonesia the species is also considered Vulnerable (IUCN 2011), but also common and widespread in the western part of the country and abundant in most areas with natural or man-made wetlands (Anonymous 2006). Recent surveys found the Indonesian populations reduced and still decreasing and locally extinct around trade centers (Schoppe 2009). A study to estimate the population size of the species in a peat swamp habitat in a nationally protected area in Sulawesi yielded 71 individuals and an estimated density of 60 individuals/ha (Schoppe 2009).

The immense market pressure on the species could result in extinction within a relatively short timeframe as predicted by Altherr and Freyer (2000).

Threats to Survival. - Large numbers of animals are caught for: 1) local consumption; 2) export mainly to Europe and North America for the pet trade; or 3) export to China for food and Traditional Chinese Medicine (TCM) (Holloway 2003). All specimens for domestic and international use are wild-caught. They are extracted year-around, disregarding size, but larger (adult) individuals are preferred for consumption and TCM trade, and smaller ones (CL 100-150 mm) for the pet trade. Cuora amboinensis was among the 10 most heavily traded chelonians during 1998-99 (Lau et al. 2000) and remains as such as least in Malaysia and Indonesia (Jensen and Das 2008; Schoppe 2008, 2009). Generally, collection for international trade for consumption and TCM are the major threats that have been identified (van Dijk et al. 2000; Ades et al. 2000; Anonymous 2002; UNEP-WCMC CITES Trade Database 2008).

Collection occurs over the entire species' range, and disregard designated collection areas and quotas in Indonesia and Malaysia (Schoppe 2008, 2009). Populations in national protected areas are exploited to a lesser extent, but since law enforcement is weak, exploitation also occurs there (Schoppe 2009). Altherr and Freyer (2000) stated that $C$. amboinensis is among the most commonly imported pet turtles. Tens of thousands were imported to Europe in the 1990s alone (Altherr and Freyer 2000). Recent studies confirmed this but identified illegal trade for the food and Traditional Chinese Medicine (TCM) trade to China as the main threat (Schoppe 2009). Chen et al. (2000) reported that the Malayan Box Turtle, along with Malayemys subtrijuga (possibly including M. macrocephala) and Siebenrockiella crassicollis, were the commonest turtles in the trade in TCM in Taiwan, accounting for over $75 \%$ of the trade, while in mainland China, along with Mauremys reevesii, C. amboinensis accounted for up to $49 \%$ of the total turtle export (Zhou and Jiang 2008). Indonesia is the main supplier of the species for the international meat, TCM, and pet markets. A conservative estimate is that illegal trade amounts to 10 times the volume of legal trade (Schoppe 2009), and this covers live specimens and the shell trade.

From Peninsular Malaysia, Sharma (1999) reported that $C$. amboinensis is the most commonly sold species in the pet trade, and that they are also released in Chinese 
temple tanks. Levels of harvest and illegal trade in Malaysia demonstrate that immediate action is needed to regulate exploitation for the future sustainable management of the species (Schoppe 2008). In TCM, the heads and shells are used as a tonic for women after childbirth. In Malaysia, the main users are indigenous groups, Thai communities along the Malaysian-Thai border, and ethnic Chinese (Schoppe 2008). Turtles illegally exported from Malaysia may pass through several countries (Thailand, Myanmar, Laos) but there are only few main final destinations for turtles traded for consumption from Malaysia: China, Hong Kong, and to lesser extent to Singapore (Schoppe 2008). Exploitation in Thailand remains at modest levels, and most collections are for release in temple tanks (van Dijk and Thirakhupt 2000).

Over 10 years ago, when the Burmese subspecies was locally numerous, McCord and Philippen (1998) already assumed a collapse of the populations due to low reproduction and continuous exploitation. This might also be true for the Philippines where the species remains locally common (Ferner et al. 2001). Alcala (1986) mentioned that in the Visayas region of the Philippines, the turtle is caught for its flesh, and is even raised in captivity. Collection for food, traditional medicine, and for the pet trade seem to be the main reasons for population declines all over the Philippines (Alviola et al. 2003; Gavino and Schoppe 2004; Diesmos et al. 2008). The species is commonly offered for sale in pet shops of the large cities such as Manila, Cebu, and Davao (Diesmos et al. 2008). It remains to be assessed if the intensive international trade mainly handled by Chinese and Taiwanese traders until the early 1990s still continues after the implementation of the Philippine Wildlife Act.

Capture techniques vary: in northeastern India and Bangladesh, the turtle is occasionally caught in gill nets set for fish. The relatively terrestrial adults may be brought out of hiding by setting fires to grass during the dry season, a practice followed in other parts of Asia. In Malaysia and Indonesia, animals are either hand captured or collected with baited traps during darkness (Schoppe 2008, 2009).

Aside from over-exploitation, habitat destruction and pollution impact populations of C.amboinensis. In Malaysia, over-exploitation and pollution of waterways were identified as threats by Lim and Das (1999), as well as the continuous clearing of Melaleuca swamps on the east coast to give way for coastal development projects (Sharma and Tisen 2000).

Conservation Measures Taken. - Cuora amboinensis and all other members of the genus Cuora were added to Appendix II of CITES in 2000 (CITES 2009). The IUCN Red List has listed the species as Vulnerable since 2000 (IUCN 2011).

This species exists in some of the wetland sanctuaries in eastern India (Manas Tiger Reserve, Kaziranga National Park, Orang Wildlife Sanctuary, and D'Ering Wildlife Sanctuary, all within Assam State, and the Galathea National Park, Nicobar Islands) and protected areas elsewhere in the range of the species in India (Das 1995). In Myanmar, it is protected under the Myanmar Wildlife Law (1994), as well as under Myanmar Fisheries Law (1993) (see Maung and Ko Ko 2002). In Thailand, this species is unprotected, but occurs in several protected areas, including the KhaoLal-Lamru National Park (Chan-Ard et al. 1999) and Doi-Suthep-Pui National Park (Wongsawad et al. 1998). In Vietnam, this species is listed as Vulnerable in the Vietnam Red Data Book (Tran et al. 2007) and recorded from the U Minh Thuong National Park (Stuart 2004). In Cambodia, the species occurs in the Tonle Sap Biosphere Reserve (Platt et al. 2008).

In Peninsular Malaysia, the species is not protected and collection for local use is unregulated. It occurs in the Penang National Park (Ibrahim et al. 2008), and presumably in other protected areas. In Sabah and Sarawak, collection for local use requires permits. The international trade was quota-regulated from 2000-04; a harvest ban for international trade was imposed in 2004 and an export ban was declared in 2005 (Schoppe 2008). When the Malaysian CITES Management Authority suspended harvest for export in 2004, it urged traders to set up breeding operations and to replace wild-caught supply (Anonymous 2004). However, this is not practiced (Schoppe 2008). It has been recorded from the Loagan Bunut National Park (Das and Jensen 2006) and Gunung Mulu National Park (Das et al. 2008), both in Sarawak, East Malaysia. In Singapore's Central Nature Reserves, both feral and local populations are reported ( $\mathrm{Ng}$ and $\mathrm{Lim} \mathrm{2010)}$, and the species has been recorded from Nee Soon National Park (Das, pers. obs.).

The Malayan Box Turtle occurs in the Tasek Merimbun Heritage Park in Brunei Darussalam (Das et al. 2008), but is unprotected under Brunei wildlife laws. The species is not protected under Indonesian wildlife laws, but is known from several protected areas. At least some 12 national protected areas include extensive wetland areas (Sriyanto et al. 2003), e.g., Taman National Rawa Aopa Watomohai (Schoppe 2009) and the Lore Lindu National Park (Ives et al. 2008), both in Sulawesi, and Danau Sentarum National Park in Kalimantan (Walter 2000). The United Nations (1997), however, stressed that these protected areas do not assure biodiversity conservation because most of them have inadequate human resources for management and regulation of enforcement. Harvest and export from Indonesia became regulated with the listing of the species in CITES Appendix II in the year 2000. As in Malaysia, the species was recommended for large-scale captive breeding for consumption trade by the Indonesian CITES Management Authority, but this was neither implemented nor developed further. Captive breeding of the Southeast Asian Box Turtle for commercial profit is at present not economically feasible in a country of export, where captive-bred animals incur high air-freight rates (Schoppe 2008).

In the Philippines the species is covered under the Philippine Wildlife Act (RA 9147), a law that prohibits collection and trade of wildlife without a permit. The Philippine CITES Management Authority has banned the export of wild-caught 
individuals since no non-detriment-finding studies - a requirement for CITES Appendix II listing species - have been conducted so far. Despite the country's extensive network of protected areas, only a very few cover freshwater wetlands. Insufficient human resources and funds for patrolling further weaken this potential conservation measure.

Conservation Measures Proposed. - Monitoring trade levels, especially the huge illegal trade, should be instituted in many areas, and improved control of the numbers of turtles in international trade may need to be recommended. All exporting countries should conduct status surveys to assess whether the export of animals is negatively affecting the survival of the species in the wild (non-detriment-findings), as required by CITES for species listed on Appendix II. A careful investigation of the dynamics of the illegal trade and exploitation of this and other freshwater turtle species is also critical for conservation and management purposes.

Population size studies to determine trends over time should be conducted range-wide and in different habitat types. In the absence of quantitative data on local populations, criteria that might indicate changes in local abundance should be assessed and monitored. Relatively little is known about the biology and ecology of the species; it is recommended that baseline research on the reproduction, home range, and population densities of wild populations be conducted. Identifying habitat preferences of the species is needed for proper management, which may lead to recommendations for the protection of certain habitat types in selected areas.

The effectiveness and implementation of national legislation pertaining to freshwater turtle conservation should be assessed. Improved law enforcement to eradicate illegal trade for the food and TCM should be a priority conservation measure. Information education campaigns to raise awareness on the conservation status, biology, ecology, threats and legal status should be conducted. Trade in the species from at least two protected areas - U Minh Thuong National Park in Vietnam (Stuart 2004) and the Tonle Sap Biosphere Reserve in Cambodia (Platt et al. 2008) has been reported.

At this point we recommend prioritizing the protection of the species in its natural habitat rather than ex-situ measures. We do, however, support the maintenance of some "assurance colonies" comprising individuals that are presently held in captivity by private wildlife collectors and government-confiscated animals from the illegal trade but of known provenance. The feasibility of captive breeding for the pet trade should be assessed.

Because it is possible that $C$. amboinensis as currently recognized may be a species complex, a thorough molecular phylogeographic study of this taxon is desperately needed if we are to protect its diversity. The resulting gene tree could also be used as a forensic tool to identify the origins of confiscated specimens and animals in the trade.

Captive Husbandry. - Most data on the biology of the species derive from small-scale $e x$-situ captive breeding (e.g., Kerlen 2002, 2004, 2005; Struijk and Woldring 2005).
Hematological studies on the species, relevant to captive husbandry, were conducted by Perpiñán et al. (2008). There are some indications that successful breeding at small but commercial scale is taking place in some facilities in southern China (P.P. van Dijk, pers. comm.). In captivity, eggs are normally deposited 35-50 days after mating (Highfield 1996). Ten females kept isolated from males continued laying fertile eggs in the first year after being separated (Schoppe, pers. obs.).

Mudde (1987) found the species to be resistant to changes in temperatures, his animals accepting mosquito larvae, but not much plant matter, except water plants such as Lemna spp. and Cryptocoryne spp. Frogs, grated coconuts, and succulent leaves are eaten by the Southeast Asian box turtle in captivity, according to Alcala (1986), the diet of the species in captivity, in general, being omnivorous. Most feeding takes place in water, with food given on land usually dragged underwater. Praedicow (1985) noticed that males fed throughout the year, but females almost stopped feeding two months prior to egg-laying. For the Palawan population, this cannot be confirmed, and both sexes are voracious eaters, year around (Schoppe, pers. obs.).

Current Research. - Schoppe $(2008$, 2009) conducted studies to estimate population sizes in Indonesia and Malaysia in recent years, and similar studies in the Philippines are being planned. She is also studying reproduction and growth in the Palawan population. The environmental NGO, Katala Foundation Inc., has signed a memorandum of agreement with the local authorities in the Philippines for the conservation of this and other freshwater turtles in the Philippines. Current activities focus on information education campaigns and the monitoring of illegal trade of Cuora amboinensis and other wildlife in Palawan.

Acknowledgments. - Related work by Schoppe in Indonesia and Malaysia was funded by TRAFFIC Southeast Asia through the US State Department and the British High Commission in Kuala Lumpur. Das was supported by the Centre for Herpetology, Madras Crocodile Bank Trust, and Universiti Malaysia Sarawak. Chris Banks, Melbourne Zoological Gardens; David Emmett, Conservation International; Edward O. Moll, Eastern Illinois University; Peter Paul van Dijk, Conservation International; and Peter Widmann, Katala Foundation Inc., provided unpublished information. Finally, we thank Genevieve V.A. Gee for reading an early draft of this manuscript and John Iverson for recent references on this species.

\section{LITERATURE CITED}

Ades, G., Banks, C.B., Buhlmann, K.A., Chan, B., Chang, H.-C., Chen, T.-H., Crow, P., Haupt, H., Kan, R., Lai, J.-Y., Lau, M., Lin, H.-C., AND SHI, H. 2000. Turtle trade in Northeast Asia: Regional summary (China, Hong Kong, and Taiwan).In:vanDijk,P.P., Stuart, B.L., and Rhodin,A.G.J.(Eds.).Asian Turtle Trade: Proceedings of a Workshop on Conservation and Trade of Freshwater Turtles and Tortoises in Asia. Chelonian Research Monographs 2:52-54. 
AlCALA,A.C. 1986. Guide to Philippines Flora and Fauna. Volume X. Amphibians and Reptiles. Natural Resources Management Center, Ministry of Natural Resources and University of the Philippines, Manila, $195 \mathrm{pp}$.

AltherR,S. ANDFREYER,D. 2000.The decline of Asianturtles.Munich: Pro Wildlife, $23 \mathrm{pp}$.

Alviola, P.L., III., Cosisco, E.A., ANd Eres, E.G. 2003.Determination of relative age, sex, and sex ratio of the Malayan Box Turtle (Cuora amboinensis Daudin) in Pinaglubayan, Polillo Island. Quezon, Philippines. Asia Life Sciences 12:111-121.

ANONYMOUS. 2002. Kuota pengambilan tumbuhan alam dan penangkapan satwa liar untuk periode tahun 2002. Keputusan Direktur Jenderal Perlindungan Hutan Dan Konservasi Alam.

ANONYMOUs. 2004. Convention on International Trade in Endangered Species of Wild Fauna and Flora. Thirteenth meeting of the Conference of the Parties, Bangkok. CoP13 Doc. 33, 10 pp.

ANONYMOUs. 2006. Convention on International Trade in Endangered Species of Wild Fauna and Flora. Fifty-fourth meeting of the Standing Committee. SC54 Doc. 42.

AzRINA, L.A. AND LIM, B.-L. 1999. Legislative status of chelonian species in Selangor, Peninsular Malaysia. Malayan Nature Journal 53(3):253-261.

Baillie, J. AND Groombridge, B. 1996. 1996 IUCN Red List of Threatened Animals. Gland: IUCN, 378 pp.

BARNETT, S. 2003. Entamoeba invadens: the chelonian connection. Terrapin Tales March 2003:1-5.

BELL, T. 1826. A monograph of the tortoises having a moveable sternum, with remarks on their arrangement and affinities. Zoological Journal, London 2:299-310.

BERRY, J.F. 1984. Redescription of Falcaustra duyagi (Tubangui \& Villaamil,1933)Freitas \&Lent, 1941 (Nematoda:Cosmocercoidea) from Cuora amboinensis (Testudinidae) of Malaysia. Canadian Journal of Zoology 62:1685-1688.

BHASKAR, S. 1981. Travels in the Andaman and Nicobar Islands-1979. Hamadryad 6(1):2-8.

Bourret, R.L. 1941. Les tortues de l'Indochine. Inst. Océanograph. l'Indochine. 38:1-235.

BOWLER, J.K. 1977. Longevity of reptiles and amphibians in North American collections as of 1 November 1975. Society for the Study of Amphibians and Reptiles, Miscellaneous Publications, Herpetological Circular 6:1-32.

Bramble, D.M. 1974. Emydid shell kinesis: biomechanics and evolution. Copeia 1974:707-727.

Brooks, D.R. ANd Palmieri, J.R. 1978. Pronocephalid trematodes from a Malaysian box turtle including a new species of Renigonius Mehra, 1939. Proceedings of the Helminthological Society of Washington 45:34-36.

Brooks, D.R. AND PALMIERI, J.R. 1979. Neopronocephalus orientalis sp. n. (Digenea: Pronocephalidae) and Spirhapalum elongatum Rohde, Lee, and Lim, 1968 (Digenea: Spirorchiidae) from Cuora amboinensis (Daudin) in Malaysia. Proceedings of the Helminthological Society of Washington 46:55-57.

Buhlmann, K.A., Akre, T.S.B., Iverson, J.B., Karapatakis, D., MitTERMEIER, R.A., GEORges, A., RHODIN, A.G.J., vAN DiJK, P.P., AND GibBons, J.W. 2009. A global analysis of tortoise and freshwater turtle distributions with identification of priority conservation areas. Chelonian Conservation and Biology 8(2):116-149.

CARR, J.L. AND BICKHAM, J.W. 1986. Phylogenetic implications of karyotype variation in the Batagurinae (Testudines: Emydidae). Genetica 70:89-106.

Chan-Ard, T., Grossmann, W., Gumprecht, A., and Schulz, K.-D. 1999.Amphibians andReptiles of Peninsular Malaysia andThailand: An Illustrated Checklist/Amphibien und Reptilien der Halbinsel
Malaysia und Thailands: eine illustrierte Checkliste. Würselen: Bushmaster Publications, 240 pp.

Chen, T.-H., Lin, J.-C., And Chang, H.-C. 2000. Current status and utilization of Chelonians in Taiwan. In: van Dijk, P.P., Stuart, B.L. and A.G.J. Rhodin (eds.). Asian Turtle Trade: Proceedings of a Workshop on Conservation and Trade of Freshwater Turtles and Tortoises in Asia. Chelonian Research Monographs 2:45-51.

CHou,L.M.ANDLowe,C.M.1984.Spironourarobertisp.n.(Nematoda: Kathlaniidae) from the Malayan box-tortoise Cuora amboinensis. Malayan Nature Journal 38:67-72.

CITES. 2009. Appendices I, II and III. http://www.cites.org/.

DAS, I. 1991. Colour Guide to the Turtles and Tortoises of the Indian Subcontinent. Portishead: R \& A Publishing Limited, 133 pp.

DAs, I. 1995. Turtles and Tortoises of India. Bombay: Oxford University Press, $176 \mathrm{pp}$

Das, I., Clark, B., Clark, S., ANd McArthur, E. 2008. An inventory of reptiles of Gunung Mulu National Park, Sarawak, Malaysia (Borneo). Sarawak Museum Journal 63(84):127-167.

DAs, I. AND JENSEN, K.A. 2006. The herpetofauna of Loagan Bunut. In: Tuen, A.A., Sayok, A.K., Toh, N., and Noweg, G.T. (Eds.). Scientific Journey Through Borneo: Loagan Bunut. A Scientific Expedition on the Physical, Chemical,Biological, and Sociological Aspects. Kota Samarahan: Peat Swamp Forest Project, Sarawak Forest Department and Institute of Biodiversity and Environmental Conservation, Universiti Malaysia Sarawak, pp. 131-154.

DAS,I.,NYAWA,S.B.ANDCHARLES,J.K.2008.AGuide to the Amphibians and Reptiles of Tasek Merimbun Heritage Park,BruneiDarussalam. Brunei Museums Department, Bandar Seri Begawan, 92 pp.

Daudin, F.-M. 1802. Histoire Naturelle, Génerale et Particulière des Reptiles. Vol. 2. Paris: F. Dufart, 432 pp.

Diesmos, A.C., Brown, R.M., Alcala, A.C., AND Sison, R.V. 2008. Status and distribution of non-marine turtles of the Philippines. Chelonian Conservation and Biology 7(2):157-177.

DU Preez, L.H. AND LiM, L.H.S. 2000. Neopolystoma liewi sp. n. (Monogenea: Polystomatidae) from the eye of the Malayan box turtle (Cuora amboinensis). Folia Parasitologica 47:11-16.

DwIVEDI, M.P. 1965. On a new sp. of the genus Spinometra Mehra, 1931 (Plagiorchiidae: Astiotrematinae). Revista de Biología Tropical 13:91-99.

DwIVEDI, M.P. 1967. Kachugotrema amboinensis n.g. n. sp. (Paramphistomidae: Trematode). Indian Journal of Helminthology 19:45-55.

ERnst, C.H.,Altenburg, R.G.M., AND Barbour, R.W.2000.Turtles of the World. World Biodiversity Series. Biodiversity Center of ETI, ETI/NLBIF, www.nlbif.eti.uva.nl/bis/turtles.php.

ERnst, C.H., Lovich, J.E., LaEmmerzahl, A.F., AND SeKsciensKi, S. 1997. A comparison of plastral scute lengths among members of the box turtle genera Cuora and Terrapene. Chelonian Conservation and Biology 2(4):603-607.

EWERT, M.A. 1979. The embryo and the egg: development and natural history.In:Harless, M. and Morlock,H.(Eds). Turtles: Perspectives and Research. New York: Wiley Interscience, pp. 333-416.

Ferner, J.W., Brown, R.M., Sison, R.V., AND KenNedy, R.S. 2001. The amphibians and reptiles of Panay Island, Philippines. Asiatic Herpetological Research 9:34-70.

FidENCI, P. 2004. Discovery of a wild population of the critically endangered Philippine Forest Turtle Heosemys leytensis, in Palawan Philippines. Turtle and Tortoise Newsletter 8:2-3.

FidenCI, P. AND CASTILLO, R. 2009. Some data on the distribution, conservation status and protection of freshwater turtles in the Palawan Island Group, Philippines. Testudo 7(2):76-87.

FRAZIER, J.G. AND DAS, I. 1994. Some notable records of Testudines from the Indian and Burmese Subregions. Hamadryad 19:47-66. 
FRITZ, U. AND HaVAS, P. 2007. Checklist of chelonians of the world. Vertebrate Zoology 57:149-368.

GaUlKe, M. 1995a. On the distribution of emydid turtles and the anuran genus Microhyla in the Philippines. Asiatic Herpetological Research 6:49-52.

GAULKE, M. 1995b. Der Sulu-Archipel-Besiedlungsgeschichte, Geologie und Herpetofauna. Natur und Museum 125:217-226.

GAULKE, M. AND FRITZ, U. 1998. Distribution patterns of batagurid turtlesin thePhilippines (Testudines: Bataguridae: Cuora, Cyclemys, Heosemys). Herpetozoa 11(1/2):3-12.

GaVINo, C.M. AND SCHOPPE, S. 2004. First information on the trade of freshwater turtles in Palawan. Agham Mindanaw, Ateneo de Davao Journal of Science and Technology 2:53-60.

Gorman, G.C. 1973. The chromosomes of the Reptilia, a cytotaxonomic interpretation. In: Chiarella, A.B. and Capanna, E. (Eds). Cytotaxonomy and VertebrateEvolution.London:Academic Press, pp. 349-424.

GrEGORY,R.ANDSHarma,D.S.K. 1997.Review of legislation affecting marine and freshwater turtles, terrain, and tortoise conservation and management in Malaysia: recommendations for change. Kuala Lumpur: WWF Tabung Alam Malaysia Project Report, 45 pp.

GRYCHTA,U.1989.Cuora amboinensis-DieAmboine-Scharnierschildkröte. Ein Bericht über Haltung Paarungsverhalten, Eiablage und gelungener Nachzucht. Aquarien und Terrarien 36:134-135.

Guo,C.-W. 1997.A study on chromosomes of Chinese chelonians. In: Chinese Chelonian Research. Herpetological Series (9). Sichuan Journal of Zoology 15 (Supplement): 93-96. [In Chinese with English abstract.]

HENDRIE,D.B.2000. Status and conservation of tortoises and freshwater turtles in Vietnam.In: vanDijk,P.P.,Stuart,B.L., and Rhodin,A.G.J. (Eds.). Turtle Trade: Proceedings of a Workshop on Conservation and Trade of Freshwater Turtles and Tortoises in Asia. Chelonian Research Monographs 2:63-73.

HigHFIELD,A.C. 1996.PracticalEncyclopaedia of Keeping and Breeding Tortoises and Freshwater Turtles. Llandysul, Dyfed, Wales: Gomer Press, 295 pp.

HiLTON-TAYLOR, C. 2000. 2000 IUCN Red List of Threatened Species. Gland: IUCN, $61 \mathrm{pp}$.

Holloway, R.H.P. 2003. Domestic trade of tortoises and freshwater turtles in Cambodia. Linnaean Fund Research Report. Chelonian Conservation and Biology 4:733-734.

Honda, M., Yasukana, Y., Hirayama, R. and Ota, H. 2002. Phylogenetic relationships of the Asian box turtles of the genus Cuora sensu lato (Reptilia: Bataguridae) inferred frommitochondrial DNA sequences. Zoological Science 19:1305-1312.

Ibrahim, J., Sah, S.A.M., Ahmad, N., Chan, K.O., and AKIL, M.A.M.M. 2008. The Common Amphibians and Reptiles of Penang Island. Georgetown: Jabatan Perhutanan Negeri Pulau Pinang, 116 pp.

INSKEEP, R. 1984a. A note on the captive breeding of the box turtle Cuora amboinensis (Daudin, 1802). British Journal of Herpetology 6:383-384.

INSKEEP, R. 1984b. Second breeding of Cuora amboinensis (Daudin, 1802). British Herpetological Society Bulletin 9:28.

IVERSON,J.B. 1992.ARevised Checklist with Distribution Maps of the Turtles of the World. Richmond, IN: Privately published, $363 \mathrm{pp}$.

Ives,I.E.,Platt,S.G.,Tasirin,J.S.,HunOwu,I.,Siwu,S.,ANDRAinwater, T.R.2008.Field surveys, natural history observations, and comments on the exploitation and conservation of Indotestudoforstenii, Leucocephalon yuwonoi, and Cuora amboinensis in Sulawesi, Indonesia. Chelonian Conservation and Biology 7(2):240-248.

IUCN 2009. 2009 IUCN Red List of Threatened Species. Version 2009.2. <http://www.iucnredlist.org/>.
IUCN 2011. IUCN Red List of Threatened Species. Version 2011.1. $<w w w . i u c n r e d l i s t . o r g>$.

Jenkins, M.D. 1995. Tortoises and Freshwater Turtles: The trade in Southeast Asia. Cambridge: TRAFFIC International, 48 pp.

JeNSEN, K.A. AND DAS, I. 2006. Biological observations on the Asian soft-shell turtle in Sarawak, Malaysian Borneo, with notes on the biology and conservation of other non-marine turtles. Testudo 6(3):39-49.

JENSEN, K.A. AND DAS, I. 2008a. Observations on the influence of seasonality, lunar cycles, and weather condition on freshwater turtle activity in Sarawak,East Malaysia(Borneo).AsiaticHerpetological Research 11:37-42.

JensEN, K.A. AND DAS, I. 2008b. Cultural exploitation of freshwater turtles in Sarawak, Malaysian Borneo. Chelonian Conservation and Biology 7(2):281-285.

Kabir, S.M.H.,Ahmad, M.,Ahmed, A.T.A.,RAhman, A.K.A.,AhMEd, Z.U.,BEGUM,Z.N.T.,HASSAN,M.A. ANDKHANDKER,M.(Eds.). 2009. Encyclopedia of Flora andFauna ofBangladesh.Vol.25.Amphibians and Reptiles. Dhaka: Asiatic Society of Bangladesh, 204 pp.

KeRLEn,M.2002.Studbook Breeding Programme.Cuora amboinensis Malayan box turtle.European Studbook Foundation. Interim report 2002, September 2002. www.studbooks.org.

KerLen,M.2004.StudbookBreeding Programme.Cuora amboinensis Malayan box turtle. Report September 2002 - April 2004. www. studbooks.org.

KerLen,M.2005.StudbookBreeding Programme.Cuoraamboinensis Malayan box turtle. Report April 2004 - December 2004. www. studbooks.org.

KILLEBREw,F.1977.Mitotic chromosomes of turtles.IV.TheEmydidae. Texas Journal of Science 29:245-253.

Kolisko, M., Cepicka, I., Hampl, V., Leigh, J., Roger, A.J., Kulda, J., Simpson, A.G.B., AND FLEGR, J. 2008. Molecular phylogeny of diplomonads and enteromonadsbased on SSU rRNA, alpha-tubulin and HSP90 genes: Implications for the evolutionary history of the doublekaryomastigont of diplomonads. BMCEvolutionaryBiology 8:205, doi: 10.1186/1471-2148-8-205.

KuChling, G., Rhodin, A.G.J., IBARRONDO, B.R., AND Trainor, C.R. 2007. Anew subspecies of the snakeneck turtle Chelodina mccordi from Timor-Leste (East Timor) (Testudines: Chelidae). Chelonian Conservation and Biology 6(2):213-222.

LAU,M.,ChAn,B.,Crow,P., ANDAdEs,G. 2000.Trade and conservation of turtles and tortoises in the Hong Kong Special Administrative Region, People's Republic of China. In: van Dijk, P.P., Stuart, B.L., and Rhodin, A.G.J. (Eds.). Asian Turtle Trade: Proceedings of a Workshop on Conservation and Trade of Freshwater Turtles and Tortoises in Asia. Chelonian Research Monographs 2:39-44.

LiM,B.L. ANDDAS,I. 1999. Turtles of Borneo and Peninsular Malaysia. Kota Kinabalu: Natural History Publications (Borneo) Sdn. Bhd., $151 \mathrm{pp}$.

MAUNG,W.ANDKoKo,W.2002.Turtles and Tortoises of Myanmar.Yangon: Wildlife Conservation Society (Myanmar Program), 94 pp.

McCord, W.P. AND Iverson, J.B. 1991. A new box turtle of the genus Cuora (Testudines: Emydidae) with taxonomic notes and a key to the species. Herpetologica 47(4):407-420.

McCord, W.P. And PhILIPPEn, H.-D. 1998. A new subspecies of box turtle,Cuoraamboinensislineata,fromnorthernMyanmar(Burma), with remarks on the distribution and geographic variation of the species. Reptile Hobbyist 3:51-58.

Moll, D. And Moll, E.O. 2004. The Ecology, Exploitation, and Conservation of River Turtles. Oxford: Oxford University Press, $393 \mathrm{pp}$.

MoLL,E.O.1997.Effects of habitat alteration on riverturtles of tropical Asia with emphasis on sand mining and dams. In: van Abbema, J. 
(Ed.). Proceedings: Conservation, Restoration, and Management of Tortoises and Turtles - An International Conference, July 1993, State University of New York, Purchase. New York: New York Turtle and Tortoise Society, pp. 37-41.

MudDE,P.1987.Voortplanting van deAmbonese dooschildpad(Cuora amboinensis) in het terrarium. Lacerta 45:70-80.

MurRay, R.A. 2004. Endohelminths from six rare species of turtles (Bataguridae) from Southeast Asia confiscated by international authorities in Hong Kong, China. Masters Thesis, Texas A\&M University, College Station.

Myers, B.J. AND Kuntz, R.E. 1969. Nematodes of fishes, amphibians, and reptiles taken by U.S. Naval Medical Research Unit No. 2 expedition to north Borneo (Malaysia). Journal of the Fisheries Research Board of Canada 26:793-797.

Natchev, N., Heiss, E., Lemell, P., Stratev, D., and Weisgram, J. 2009. Analysis of prey capture and food transport kinematics in two Asian box turtles, Cuora amboinensis and Cuora flavomarginata (Chelonia, Geoemydidae), with emphasis on terrestrial feeding patterns. Zoology, Jena 112(2):113-27.

NG, T.H. AND LIM, K.K.P. 2010. Introduced aquatic herpetofauna of Singapore's reservoires. Cosmos 6(1):117-127.

NutAPHAND, W. 1979. The Turtles of Thailand. Bangkok: Siam Farm Zoological Gardens, 222 pp.

Palmieri, J.R. ANd Sullivan, J.T. 1977. Stunkardia minuta sp. n. (Trematoda: Paramphistomidae) from the Malayan box-tortoise Cuora amboinensis. Journal of Helminthology 51:21-124.

Paull, R.C., Reimer, D.N., AND Nicol, E.B. 1982. Malayan box turtle Cuora amboinensis (Daudin 1802). Turtle Trust Occasional Paper, 2 pp.

Perpiñán, D., Hernandez-Divers, S.M., Latimer, K.S., Akre, T., Hagen, C., Buhlmann, K.A., and Hernandez-Divers, S.J. 2008. Hematology of the Pascagoula map turtle (Graptemys gibbonsi) and the Southeast Asian box turtle (Cuora amboinensis). Journal of Zoo and Wildlife Medicine 39(3):460-463.

Platt, S.G., Sovannara, H., Kheng, L., Long, K., Holloway, R., StuART,B.L., ANDRAINWATER, T.R.2008.Biodiversity, exploitation, and conservation of turtles in the Tonle Sap Biosphere Reserve, Cambodia, with notes on reproductive ecology of Malayemys subtrijuga. Chelonian Conservation and Biology 7(2):195-204.

Praedicow, G. 1985. Langjährige Erfahrungen bei der Pflege von Cuora amboinensis (Daudin). Herpetofauna 7(37):6-14.

RASHID, S.M.A. AND KHAN, S.M.H. 2000. Overview of turtle trade in Cambodia.In: vanDijk,P.P.,Stuart,B.L., andRhodin,A.G.J.(Eds.). Asian Turtle Trade: Proceedings of a Workshop on Conservation and Trade in Freshwater Turtles and Tortoises in Asia. Chelonian Research Monographs 2:77-85.

RHodin, A.G.J. 2003. Conservation and trade of Asian freshwater turtles and tortoises: updated review of status and threats with recommendations for CITES listings. AC19 Doc. 15.1.

Richardson, J.P.M. AND BROOKs, D.R. 1987. Polystomoidella mayesi n. sp. (Monogenean: Polystomatidae) from the urinary bladder of a Malaysian box turtle, Cuora amboinensis. Canadian Journal of Zoology 65:1567-1569.

Rogner, M. 1996. Schildkröten 2. Kinosternidae Platysternidae Testudinidae Trionychidae Carettochelyidae Cheloniidae Dermochelyidae Chelidae Pelomedusidae. Hürtgenwald: Heidi Rogner-Verlag, 265 pp.

RoHDE, K. 1962a. A new trematode, Diaschistorchis multitesticularis sp. n., from a Malayan tortoise, Hieremys annandalei (Boulenger). Journal of Parasitology 48:296-297.

RoHDE,K.1962b.Parorientodiscusmagnusn.g.,n.sp.,Ein Trematode aus dem Darm von Cyclemys amboinensis (Daudin) in Malaya. Zeitschrift für Parasitenkunde 21:457-464.
RoHDE, K. 1963. Polystomoides malayi n. sp. (Monogenea, Polystomatidae) aus derHarnblase von Cyclemys amboinensis in Malaya. Zeitschrift für Parasitenkunde 22:278-282.

RoHDE, K. 1971. Untersuchungen an Multicotyle purvisi Dawes, 1941 (Trematoda: Aspidogastrea). I. Entwicklung und Morphologie. Zoologische Jahrbücher, Abteilung für Anatomie 88:138-187.

RoHDE, K. 1972b. The Aspidogastrea, especially Multicotyle purvisi Dawes, 1941. Advances in Parasitology 10:77-151.

RoHDE, K., LeE S.K., AND Lim, H.W. 1968. Über drei malayische Trematoden. Annales de Parasitologie 43:33-43.

RuMMLER, H.-J. AND FRITZ, U. 1991. Geographische Variabilitat der Amboina-Scharnierschildkröte Cuora amboinensis (Daudin, 1802), mit Beschreibung einer neuen Unterart, C.a. kamaroma subsp. nov. Salamandra 27:17-45.

SALTER, R.E. 1993. Wildlife in Lao PDR. A status report. Vientiane: IUCN - The World Conservation Union.

SAXENA, A. 1994. Captive breeding of the Malayan box turtle (Cuora amboinensis) from the Nicobar Islands. Hamadryad 19:93-94.

SCHOPPE, S. 2008. Science in CITES: The Biology and Ecology of the Southeast Asian Box Turtle Cuora amboinensis and its Uses and Trade in Malaysia. Petaling Jaya, Selangor: TRAFFIC Southeast Asia, $56 \mathrm{pp}$.

SCHOPPE, S. 2009. Status, trade dynamics and management of the Southeast Asian Box Turtle Cuora amboinensis in Indonesia. Petaling Jaya, Selangor: TRAFFIC Southeast Asia, 90 pp.

SCHOPPE, S., 2010. Die kleinste Südostasiatische Scharnierschildkröte Cuora amboinensis. Marginata 26(1):40-45.

SchweIgGer, A.F. 1812. Prodromus monographiae cheloniorum. Königsberger Archiv für Naturwissenschaft und Mathematik, Königsberg 1:271-358, 406-458.

Sey, O. ANd Palmieri, J.R. 1978. Histo-morphological structure of the muscular organs of Stunkardia minuta Palmieri et Sullivan, 1977 (Trematoda: Paramphistomata). Parasitologia Hungarica 11:27-29.

Sharma, D.S.K. 1999. Tortoise and Freshwater Turtle Trade and Utilisation in Peninsular Malaysia. Petaling Jaya: TRAFFIC Southeast Asia, $39 \mathrm{pp}$.

Sharma, D.S.K. AND Tisen, O.B. 2000. Freshwater turtle and tortoise utilization and conservation status in Malaysia. In: van Dijk, P.P., Stuart, B.L., and Rhodin, A.G.J. (Eds.). Asian Turtle Trade: Proceedings of aWorkshop on Conservationand Trade in Freshwater Turtles and Tortoises in Asia. Chelonian Research Monographs 2:120-128.

SHARMA, R.S.K. 2001. Descriptive morphology, morphometry, community structure, and spatial distribution of helminth parasites in the Malayan box turtle, Cuora amboinensis (Chelonia: Bataguridae) from Peninsular Malaysia. Masters Thesis, Universiti Putra Malaysia, Serdang.

Sharma, R.S.K., Rigby, M.C., Sumita, S., SANi, R.A., Vidyadaran, M. K., JANSI, S., AND DAILEY, M.D. 2002. Redescription of Serpinema octorugatum (Baylis, 1933) (Nematoda: Camallanidae) from the Malayan box turtle Cuora amboinensis (Daudin) (Chelonia: Bataguridae). Systematic Parasitology 53:19-28.

SHEPHERD, C.R., Burgess, E.A. AND LoO, M. 2004. Demand Driven: The trade of Indian StarTortoises Geochelone elegans in Peninsular Malaysia. Kuala Lumpur: TRAFFIC Southeast Asia, 11 pp.

SRiyanto,A.,WEllesley,S.,Sugand,D.,WidJanarti,E., ANDSUtryono, D. 2003. Guidebook of 41 National Parks in Indonesia. Jakarta, Indonesia: Directorate General of Forest Protection and Nature Conservation, The United Nations Educational, Scientific and Cultural Organization and The Centre for International Forestry Research, 168 pp.

SPINKS, P.Q. AND SHAFFER, H.B. 2007. Conservation phylogenetics 
of the Asian box turtles (Geoemydidae, Cuora): mitochondrial introgression, numts, and inferences from multiple nuclear loci. Conservation Genetics 8:641-657.

STANNER, M.2010.Mammal-like feeding behavior of Varanus salvator and its conservation implications. Biawak 4(4):128-131.

Sтоск,A.D. 1972. Karyological relationships in turtles (Reptilia: Chelonia). Canadian Journal of Genetics and Cytology 14:859-868.

STRUIJK, R.P.J.H. AND WoldRING, L.A. 2005. Cuora studbooks, an overview. Radiata 14(2):64-73.

StUART, B.L. 2004. The harvest and trade of reptiles at U Minh Thuong National Park, southern Vietnam. TRAFFIC Bulletin 20(1):25-34.

TAN, E.G. AND Liu, X.Q. 2001. One new species of the genus Hemiclepsis (Rhynchobdellida: Glossiphoniidae). Acta Zootaxonomica Sinica 26:289-291.

ThIRAKhupt, K. AND van DiJK, P.P. 1994. Species diversity and conservation of turtles of western Thailand. Natural History Bulletin of the Siam Society 42:209-259.

TKACH, V.V., SNYDER, S.D., AND VAUGHAN, J.A. 2009. Anew species of blood fluke (Digenea: Spirorchiidae) from the Malayan box turtle, Cuoraamboinensis (Cryptodira: Geomydidae) in Thailand.Journal of Parasitology 95(3):743-746.

Tran, K.,Ho,C.T.,NguYen, S.V., And Pham, T.2007. Reptiles and amphibians.In: Dang, N.T., Tran,K. Dang,H.H.,Nguyen,C., Nguyen, T.N.,Nguyen, Y.N., and Dang,D.T.(Eds.).Vietnam RedData Book. Part 1. Animals. Hanoi: Forestry Department, pp. 219-276.

Tubangui, M.A. 1933. Trematode parasites of Philippine Vertebrates, VI. The Philippine Journal of Science 52:167-197.

Tubangui, M.A. and Villaamil, R. 1933. Nematodes in the collection of the Philippine Bureau of Science. I: Oxyuridea. The Philippine Journal of Science 51:607-615.

UNEP-WCMC CITES Trade Database. 2008. CITES trade statistics derived from the CITES Trade Database. Cambridge: UNEPWorld Conservation Monitoring Centre, http://sea-bov.unep-wcmc.org/ citestrade/.

United NATIONs. 1997. Indonesia, Country Profile. Implementations of Agenda 21: Review of progress made since the United Nations conference on environment and development, 1992.United Nations Department for Policy Coordination and Sustainable Development Division for Sustainable Development. http://www.un.org/dpcsd/ earthsummit.

VANDIJK,P.P.2000.The status of turtles in Asia.In: vanDijk,P.P.,Stuart, B.L., and Rhodin,A.G.J.(Eds.).Asian Turtle Trade: Proceedings of a Workshop on Conservation and Trade of Freshwater Turtles and Tortoises in Asia. Chelonian Research Monographs 2:15-18.

VAN DIJK, P.P. AND THIRAKHUPT, K. 2000. Conservation status, trade, and management of tortoises and freshwater turtles in Thailand. In: van Dijk, P.P., Stuart, B.L., and Rhodin, A.G.J. (Eds.). Asian Turtle Trade: Proceedings of a Workshop on Conservation and Trade in Freshwater Turtles and Tortoises in Asia. Chelonian Research Monographs 2:137-144.
VAN DiJK, P.P., ISKandar, D.T., PAlasuwan, T., Rhodin, A.G.J., SAMEdI, SHARMA, D.S.K., SHEPHERD, C.R., Tisen, O.B., AND GENORUPA, V.R. 2000.Turtle trade in Southeast Asia: Regional Summary (Indonesia, Malaysia,Papua NewGuinea, andThailand).In:van Dijk,P.P.,Stuart, B.L., and Rhodin,A.G.J.(Eds.). Asian Turtle Trade: Proceedings of a Workshop on Conservation and Trade of Freshwater Turtles and Tortoises in Asia. Chelonian Research Monographs, 2:145-147.

Verneau, O., Palacios, C., Platt, T., Alday, M., Billard, E., AlLIENNE, J.F., BASSO, C., AND DU PREEZ, L.H. 2011. Invasive species threat: parasite phylogenetics reveals patterns and processes of host-switching between non-native and native captive freshwater turtles. Parasitology 138(13):1778-1792.

VetTeR, H. AND van DiJK, P.P. 2006. Terralog: Turtles of the World. Vol. 4. East and South Asia. Frankfurt am Main: Edition Chimaira, $160 \mathrm{pp}$.

WALTER, O. 2000. A study of hunting and trade of freshwater turtles and tortoises (OrderChelonia) at Danau Sentarum.Borneo Research Bulletin 31:323-335.

Wharton, G.W. 1970. The genera Teleorchis, Protenes, and Auridistomum (Trematoda: Reniferidae). The Journal of Parasitology 52:497-518.

WhitAKer, R. AND ANDREws, H.V. 1997. Captive breeding of Indian turtles and tortoises at the Centre for Herpetology/Madras Crocodile Bank.In: vanAbbema,J.(Ed.).Proceedings: Conservation, Restoration, and Management of Tortoises and Turtles - An International Conference, July 1993, State University of New York, Purchase. New York: New York Turtle and Tortoise Society, pp. 166-170.

WIDMANN,P.1998.AGuide to the Ecosystems of Palawan,Philippines. Singapore: ViSCA-GTZ and Times Edition, 120 pp.

Wongsawad, C., Sey, O., Rojanapaibul, A., ChariyahpongPun, P., SuWATIANACOUPT, S.,MARAYONG, T., WongSAWAD,P., AND RoJTINNAKORN, J. 1998. Trematodes from amphibians and reptiles of Thailand. Journal of Science Society of Thailand 24:265-274.

Ye,R.,ZHENG,R.,WANG,L.,ANDDu,W.2009.Polymorphic microsatellite loci in the Chinese pond turtle (Chinemys reevesii). Conservation Genetics 10:1045-1048.

ZHOU, Z. AND JiANG, Z. 2008. Characteristics and risk assessment of international trade in tortoises and freshwater turtles in China. Chelonian Conservation and Biology 7(1):28-36.

\section{Citation Format for this Account:}

SCHOPPE, S. AND DAS, I. 2011. Cuora amboinensis (Riche in Daudin 1801) - Southeast Asian Box Turtle. In: Rhodin, A.G.J., Pritchard, P.C.H.,van Dijk,P.P.,Saumure,R.A.,Buhlmann,K.A.,Iverson,J.B., and Mittermeier, R.A. (Eds.). Conservation Biology of Freshwater Turtles and Tortoises: ACompilation Project of the IUCN/SSC Tortoise and Freshwater Turtle Specialist Group. Chelonian Research Monographs No. 5, pp. 053.1-053.13, doi:10.3854/crm.5.053. amboinensis.v1.2011, http://www.iucn-tftsg.org/cbftt/. 